\title{
Determination of Suitable Nursery Growth Media for Cardamom (Eletteria cardamomum Maton.) Seedlings at Teppi, Southwestern Ethiopia
}

\author{
Shiferaw Temteme ${ }^{1}$, Behailu Mekonnen ${ }^{1}$, Essubalew Getachew ${ }^{2}$ \\ ${ }^{1}$ Ethiopia Institute of Agricultural Research, Teppi Agricultural Research Center, Teppi, Ethiopia \\ ${ }^{2}$ College of Agriculture and Veterinary Medicine, Jimma University, Jimma, Ethiopia
}

Email address:

Shiferawtemteme@yahoo.com (S. Temteme),g.essu2011@gmail.com (E. Getachew), behailumekonnenba@gmail.com (B. Mekonnen)

\section{To cite this article:}

Shiferaw Temteme, Behailu Mekonnen, Essubalew Getachew. Determination of Suitable Nursery Growth Media for Cardamom (Eletteria cardamomum Maton.) Seedlings at Teppi, Southwestern Ethiopia. American Journal of Bioscience and Bioengineering.

Vol. 9, No. 3, 2021, pp. 68-74. doi: 10.11648/j.bio.20210903.12

Received: April 12, 2021; Accepted: June 4, 2021; Published: June 22, 2021

\begin{abstract}
Cardamom is mainly growing for its dry capsule used as a flavoring agent for food, beverages, medicinal, and source of income for the smallholder farmers in southwestern Ethiopia. Despite its advantages, the production and productivity of the crop hindered by several factors, for instance, poor agronomic practices, poor crop breeding, and management, from nursery to the main field of production. Therefore, a nursey-based experiment was conducted to identify the appropriate growth media ratios for cardamom seed germination, seedling uniformity, and vigor at Tepi, Southwestern Ethiopia. Gene cardamom variety was evaluated in six different growth media types namely; Fine Sandy Soil (FS), Forest Soil (ForS), FS: ForS (1:1), FS: DCH (Decomposed Coffee Husk) (1:1), ForS: DCH(1:1), and FS:ForS: DCH(1:1:1) and laid out in randomized complete block design with three replications. The result revealed that better cardamom seedling growth performance and vigor were obtained from a 1:1 ratio of decomposed coffee husk + forest soil growth media. Therefore, from the result, we concluded that the mixture of decomposed coffee husk + forest soil (1:1) can be used for better cardamom seedling establishment at Tepi and similar agroecology of Ethiopia. Future, studies should focus on the seedling obtained from this soil media mixture performance in the field for yield and yield components.
\end{abstract}

Keywords: Decomposed Coffee Husk, Leaf Area, Root Volume

\section{Introduction}

Cardamom is also known as the 'Queen of Spices', a perennial herb native to the evergreen forest of south India and Sri Lanka [23]. It is mainly cultivated for its fruit, which plays an important role in a variety of spicy foods, vegetables, meat dishes, tea, butter, coffee, bread, cakes as flavoring and seasoning agents. According to [8], it is also used for local sauce ' $w o t$ ' in the ground or whole forms alone or mixed with other spices. Ethiopia is the secondary center of origin for the crop and it was introduced in 1972, two cultivars were the Malabar and Mysore types as reported by [8]. After the introduction, adaptation and evaluation works were undertaken in different parts of the country. To this end, the best and promising results were observed in the hot humid lowland Western and Southwestern parts of Ethiopia.
Currently, the crop is widely adapted and grown in these areas, particularly at Teppi, Bebeka, Kabo, and its neighboring area [11].

Cardamom is a shade-loving plant, provision of an ideal shade level of $55-63 \%$ promotes its vegetative growth and development [18]. It also needs an annual rainfall of 1500 $7000 \mathrm{~mm}$, with an altitude range of 700-1400 m.a.s.l. The crop is highly susceptible to drought, supplementary irrigation during the dry spell period is required [11, 23]. Cardamom can be propagated vegetatively by the division of rhizomes and seedlings raised in nurseries. For vegetative propagation, rhizomes are dug, divided into pieces consisting of at least one old and one young shoot, planted on prepared pits. Thus, the method is simple, reliable, and less costly and plants begin bearing a year earlier than from seedlings, but division may not produce enough materials for large areas 
and materials strongly susceptible to mosaic virus or thrips $[34,37]$. On the other hand, propagation by seed is the most common and widely prevalent method among planters. A large number of seedlings can be raised without fear of disease spread compared with vegetative propagation as reported by [32]. Thus, the seed should be collected from a sound, ripe capsule on vigorous, high-yielding, disease-free plants, preferably at least 5 years old.

Nowadays, the cardamom seedlings are raised from nursery and transplanted in the main field after 6 months, it is a common practice in the Southwestern part of Ethiopia. The preliminary survey conducted in the southwestern part of Ethiopia showed that farmers used locally available media, which are not studied and supported scientifically to raise seedlings [27]. During survey observation, different growth media with different ratios of the mixture are widely practiced for cardamom and other spice seedlings by the local farmers, entrepreneurs, and state farms. Besides, three growth media (topsoil, forest soil, composts) in the mixture was also practiced by some farmers and growers, which is a growth media previously recommended for coffee seedlings [38]. According to [4], growth media is the most determining factor in the development, growth, and quality of seedlings in the nursery. It also acts as a reservoir for nutrients, moisture, and oxygen supply to the growing seedlings. Besides, a mixture of different media also plays a vital role in improving the physical and chemical properties of the soil, thereby the rate of seed germination, seedling, and root growth increase. It also provides proper aeration, sufficient moisture, and nutrients to the roots of growing seedlings, thereby vigorous growth of seedlings was attained as reported by [21] [10], and [5]. Well-aerated drained and fertile growth medium is needed for the vigorous growth of cardamom seedlings in the nursery. However, the type and ratios of growth media for spice seedlings, particularly for cardamom were not studied yet. Accordingly, this study was conducted to identify the appropriate growth media ratios for enhanced seed germination and subsequent seedling growing performance of cardamom at Tepi, Southwest Ethiopia.

\section{Materials and Methods}

\subsection{Description of the Experimental Site}

The experiment was conducted at Teppi Agricultural Research Center (TARC) nursery site from the year 20132014. The center is located at $7010^{\prime} \mathrm{N}$ latitude and $35025^{\prime} \mathrm{E}$ longitude and situated at an altitude of 1200 m.a.s.l, representing a lowland altitude according to Ethiopian traditional agro-ecological division, the elevation is the basis for this classification [7]. It is characterized by hot humid with an average annual rainfall of $1559 \mathrm{~mm}$, and a mean maximum and minimum temperature of $30.23{ }^{\circ} \mathrm{C}$ and $16.09{ }^{\circ} \mathrm{C}$, respectively $[8,9]$. The soil type of the experimental site is classified as Nitisols, which is dominated by a loam texture with a $\mathrm{pH}$ range of 5.60 to 6.0 [1]. The soil depth is very deep $(>150 \mathrm{~cm})$ and has a color of dark brown (7.5 YR3/2) when moist. The organic matter content is medium to very high (2.47 to $7.02 \%)$ according to [20] classification. The total nitrogen content is low to very high (0.09 to $0.73 \%)$ according to [31] classification, while the available phosphorus is low to medium ( 0.97 to $7.36 \mathrm{ppm})$ based on the rating of [22]. The meteorological data viz., monthly minimum and maximum temperature, and monthly rainfall data for the year 2012/13 \& 2013/14 cropping calendars were obtained from Teppi Agricultural Research Center Climate, Geospatial, and Biometrics Research Process, and presented as follow

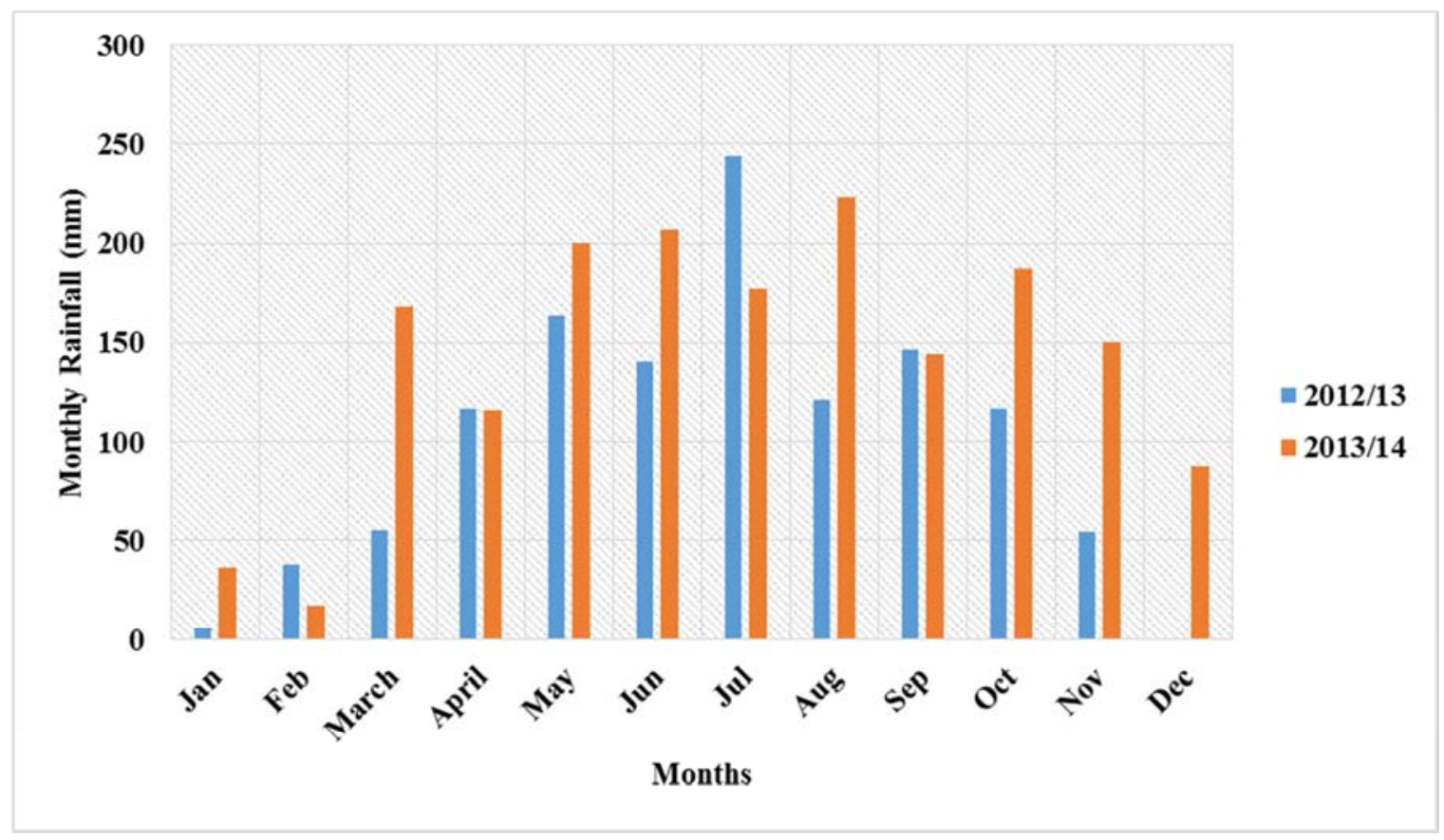

Figure 1. Monthly rainfall (mm) of the study area during 2012/13 \& 2013/14 source. 
Table 1. Monthly minimum and maximum temperature $\left({ }^{\circ} \mathrm{C}\right)$ of the study area during 2012/13 \& 2013/14.

\begin{tabular}{lllll}
\hline \multirow{2}{*}{ Months } & $\mathbf{2 0 1 2 / 1 3}$ & & $\mathbf{2 0 1 3} / \mathbf{1 4}$ \\
\cline { 2 - 5 } & Minimum & Maximum & Minimum & Maximum \\
\hline January & 11.7 & 31.8 & 12.3 & 33.6 \\
February & 13.7 & 34.7 & 13.7 & 34.2 \\
March & 15.0 & 33.4 & 14.8 & 32.6 \\
April & 15.7 & 31.7 & 15.3 & 30.6 \\
May & 15.3 & 29.0 & 14.8 & 29.0 \\
June & 15.4 & 28.4 & 14.4 & 28.6 \\
July & 15.0 & 27.2 & 14.9 & 27.4 \\
August & 14.8 & 28.2 & 14.4 & 27.4 \\
September & 15.0 & 28.3 & 14.4 & 27.2 \\
October & 13.9 & 29.2 & 14.4 & 29.3 \\
November & 12.3 & 30.4 & 14.4 & 28.4 \\
December & 9.4 & 33.1 & 14.4 & 28.6 \\
\hline
\end{tabular}

\subsection{Experimental Materials and Designs}

The treatments consisted of six growth media types viz., Fine Sandy Soil (FS) alone, Forest Soil (ForS) alone, a mixture of FS and ForS (1:1 ratio), a mixture of FS and DCH (1:1 ratio), a mixture of ForS and DCH (1:1 ratio) and a mixture of FS, ForS and DCH (1:1:1 ratios). The treatments were arranged in a Randomized Complete Block Design (RCBD) with three replications. Each treatment plot consisted of sixteen seedlings on which the treatment was applied and the data were collected. The whole experimental field was divided into three blocks each contained six plots. Then, the six treatments were randomly assigned to the unit plot of each block to allow one treatment combination only once in each block. A footpath of $0.5 \mathrm{~m}$ and $1 \mathrm{~m}$ was left between plots and blocks, respectively.

\subsection{Experimental Procedures}

All the necessary rooting or growth media types were collected, before the commencement of this experimentation. A representative forest soil (ForS) was collected from the middle forest area in the center with the upper $10 \mathrm{~cm}$ soil depth [3]. The decomposed coffee husk was collected from coffee pulping (two years old) and processing factories at Teppi town, while the fine sands (FS) were collected from the local area. Before mixing, all the collected growth media were sieved using a mesh weir of $2 \mathrm{~mm}$ to remove other soil particles, plant and animal debris, fossils [38]. The growth media composition for each treatment was prepared by volume to volume ratio according to the research works of [38] and [26] on coffee and cardamom, respectively. Each experimental growth media was subjected to soil physicochemical analysis at Tepi Regional Soil Laboratory Center using the international soil analysis procedure. The detailed results of soil physicochemical analysis are presented in Tables 2 and 3. A polybag with a size of $10 \mathrm{~cm}$ by $16 \mathrm{~cm}$ was filled with growth media according to the treatment types and arranged in rows and columns, and then watered well. The released cardamom variety viz., Gene was used for this study, the seeds were collected and processed. Three seeds were sown to each polybag with 2 to $3 \mathrm{~cm}$ depth [9] and mulched with dry vetiver grass. Watering was carried out twice a day during the initial period, later once in a day depending on daily weather conditions. Other routine cultural practices were applied as per previous recommendations $[9,15]$.

Table 2. Results of soil chemical analysis of each growth media.

\begin{tabular}{lllllll}
\hline Types of Media & $\mathbf{p H}(\mathbf{1 : 2 . 5 )}$ & $\mathbf{A v} . \mathbf{P}\left(\mathbf{m g ~ k g}^{\mathbf{- 1}}\right)$ & $\mathbf{O C} \mathbf{( \% )}$ & $\mathbf{O M}(\mathbf{\%})$ & $\mathbf{N}(\mathbf{\%})$ & $\mathbf{C : N}$ \\
\hline Fine Sandy Soil (FS) & 7.1 & 6.12 & 0.35 & 0.61 & 0.19 & 1.84 \\
Forest Soil (ForS) & 6.4 & 10 & 5.38 & 10.05 & 2.88 & 1.87 \\
Decomposed Coffee Husk (DCH) & 5.8 & 25.64 & 14.82 & 25.55 & 3.91 & 3.79 \\
FS + ForS (1:1) & 6.7 & 8.7 & 1.27 & 2.19 & 0.34 & 3.74 \\
FS + DCH (1:1) & 6.1 & 6.38 & 3.78 & 6.51 & 0.33 & 11.46 \\
ForS + DCH (1:1) & 5.9 & 7.9 & 10.41 & 17.94 & 7.46 & 1.4 \\
FS + ForS + DCH (1:1:1) & 6.1 & 34.89 & 4.95 & 8.54 & 0.94 & 5.27 \\
\hline
\end{tabular}

Source : FS=Fine Sandy Soil; ForS=Forest Soil; DCH=Decomposed Coffee Husk; Av.P=Available Phosphorus; OC=Organic Carbon, OM=Organic Matter, $\mathrm{N}=$ Nitrogen, $\mathrm{C}: \mathrm{N}=$ Carbon to Nitrogen ratio.

Table 3. Results of soil physical analysis of each growth media.

\begin{tabular}{|c|c|c|c|c|}
\hline Types of Media & Sand $(\%)$ & Clay (\%) & Silt (\%) & Textural Class \\
\hline Fine Sandy Soil (FS) & 88 & 8 & 4 & Sand \\
\hline Forest Soil (ForS) & 38 & 32 & 30 & Clay loam \\
\hline Decomposed Coffee Husk (DCH) & 20 & 46 & 34 & Clay \\
\hline $\mathrm{FS}+\mathrm{DCH}(1: 1)$ & 76 & 14 & 10 & Sandy loam \\
\hline ForS + DCH $(1: 1)$ & 58 & 22 & 20 & sandy clay loam \\
\hline FS + ForS + DCH $(1: 1: 1)$ & 70 & 18 & 12 & Sandy loam \\
\hline
\end{tabular}

Source: FS=Fine Sandy Soil; ForS=Forest Soil; DCH=Decomposed Coffee Husk

\subsection{Data to Be Collected}

Data on the growth of cardamom seedlings were recorded from each plot by taking 8_seedlings. These parameters included; plant height $(\mathrm{cm})$, number of the tiller $\left(\right.$ plant $\left.^{-1}\right)$, root volume $\left(\mathrm{cm}^{3}\right)$, leaf area $\left(\mathrm{cm}^{2}\right)$, total fresh biomass $(\mathrm{g})$, and total dry biomass $(\mathrm{g})$ were measured when the seedlings bear 4-5 leaves or got 6 months old [2]. According to [2], the seedlings attain their maximum growth and biomass yield 
during this growth stage at nursery and recommended for transplanting 2.5. Data Analysis

All the collected data were first checked for fitting the normality assumptions of ANOVA. Then, all data were subjected to analysis of variance (ANOVA) using SAS software [25]. The means comparison and separation were done by using the LSD (List Significance Difference) range test at a $5 \%$ level of significance $[6,12]$.

\section{Results and Discussion}

Results of this study showed that plant height, number of tiller per plant, number of leaves per plant, and leaf length were significantly influenced by growth media $(\mathrm{P}<0.5)$. Plant height was significantly influenced by sandy soil media while all other growth media types showed a non-significant difference for plant height. The maximum and minimum plant height was recorded in decomposed coffee husk + forest soil mixture $(60.98 \mathrm{~cm})$ and sandy soil media $(34.17$ $\mathrm{cm})$, respectively. Sandy soil media was recorded a minimum tiller number as compared to the other media and the maximum number of tiller was observed in decomposed coffee husk + forest soil media mixture (4.17). Hence, the higher number of leave number was recorded in decomposed coffee husk + forest soil media mixture (18.92) and the least was recorded in sandy soil media (12.08) (Table 4). The result of the study showed that all growth media types showed a non-significance difference in the leaf length of cardamom, except the sandy soil media type. However, the longest leaf was observed in decomposed Coffee husk + Sandy soil + Forest soil $(1: 1: 1)$ ratio $(20.75 \mathrm{~cm})$ and Forest soil + Sandy soil $(1: 1)$ ratio $(20.37 \mathrm{~cm})$. Whereas, shortest leaf of cardamom seedlings was recorded in Sandy soil media about $12.04 \mathrm{~cm}$ (Table 4).

Table 4. Plant height, leaf length, tiller and leaf number, of cardamom as influenced by nursery growth media at Teppi.

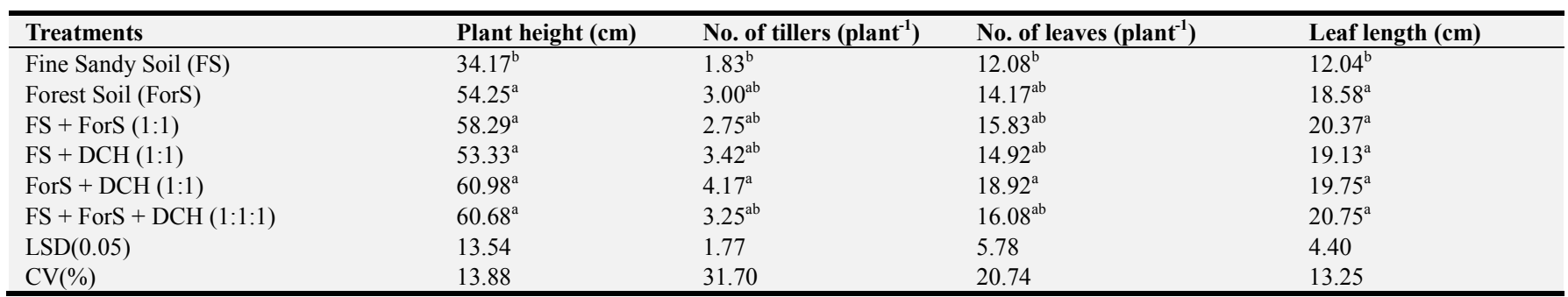

FS=Fine Sandy Soil; ForS=Forest Soil; DCH=Decomposed Coffee Husk

The increased number of leaf, tiller, and height of cardamom seedlings could be attributed to the suitability of the growth media mixture for a better source of organic matter. It also acts as a better source of nutrients, moisture, and aeration for fast germination, vigorous growth of roots, and shoot [33]. The present result in line with the research findings of $[29,28,14,16]$ and [17] on coffee, peach, and korarima seedlings, respectively. Whereas, the retarded growth of cardamom seedlings on the sandy growth media might be associated with the poor sources of the media for nutrient and moisture for the growing seedlings. This result is also supported by [13] and [19], who reported the negative responses of sandy growth media alone on the availability of moisture, nutrient, and aeration for the growing seedlings.
On the other hand, the leaf area and root volume of the cardamom seedlings were greatly influenced by growth media types. However, the growth media did not show a significant difference in the root length of cardamom seedlings (Table 5). The maximum and minimum leaf areas were observed on Decomposed coffee husk + Forest soil + Sandy soil (1:1:1) mixed media $\left(70.79 \mathrm{~cm}^{2}\right)$ and sandy soil media alone $(32.22$ $\mathrm{cm}^{2}$ ), respectively (Table 5). Hence, Sandy soil + Forest soil (1:1) media showed that a significant difference over sandy soil media in root volume, the rest of the media were not significantly different from each other. In this regard, the highest and lowest root volume of the cardamom was recorded in Sandy soil + Forest soil (1:1) media (12.92 ml) and Sandy soil media $(5.17 \mathrm{ml})$, respectively.

Table 5. Effects of different nursery growth media on root length, root volume and leaf area of cardamom seedlings at Teppi.

\begin{tabular}{llll}
\hline Treatments & Leaf Area $\left(\mathbf{c m}^{\mathbf{2}}\right)$ & Root Length $(\mathbf{c m})$ & Root Volume $(\mathbf{m l})$ \\
\hline Fine Sandy Soil (FS) & $32.22^{\mathrm{b}}$ & $35.83^{\mathrm{ns}}$ & $5.17^{\mathrm{b}}$ \\
Forest Soil (ForS) & $59.37^{\mathrm{a}}$ & $40.83^{\mathrm{ns}}$ & $6.54^{\mathrm{ab}}$ \\
FS + ForS (1:1) & $68.34^{\mathrm{a}}$ & $49.93^{\mathrm{ns}}$ & $12.92^{\mathrm{a}}$ \\
FS + DCH (1:1) & $60.76^{\mathrm{a}}$ & $47.87^{\mathrm{ns}}$ & $11.42^{\mathrm{ab}}$ \\
ForS + DCH (1:1) & $68.65^{\mathrm{a}}$ & $49.87^{\mathrm{ns}}$ & $11.54^{\mathrm{ab}}$ \\
FS + ForS + DCH (1:1:1) & $70.79^{\mathrm{a}}$ & $45.02^{\mathrm{ns}}$ & $12.04^{\mathrm{ab}}$ \\
LSD $(0.05)$ & 21.93 & 16.32 & 6.63 \\
CV $(\%)$ & 20.00 & 20.00 & 36.67 \\
\hline
\end{tabular}

FS=Fine Sandy Soil; ForS=Forest Soil; DCH=Decomposed Coffee Husk

The fresh and dry weight of shoot and roots of cardamom seedlings were significantly $(\mathrm{p}<0.05)$ influenced by different 
growth media. Accordingly, decomposed coffee husk + forest soil + sandy soil $(1: 1: 1)$, decomposed coffee husk + forest soil (1:1), and sandy soil + forest soil (1:1) media mixtures were significantly different from sandy soil both in fresh and dry weight of shoot and root of cardamom seedlings (Table 6). However, all growth media mixtures and forest soil alone were not statistically significantly different from each other. The highest fresh weight of shoot (41.83g) and root (14.29g) were recorded similarly from decomposed coffee husk + forest soil (1:1) media mixture, while the lowest values $(10.29 \mathrm{~g})$ and $(5.25 \mathrm{~g})$ were recorded from sandy soil alone media, respectively. Similarly, the highest $(4.37 \mathrm{~g} \& 1.28 \mathrm{~g})$ and lowest $(1.4 \mathrm{~g} \& 0.5 \mathrm{~g})$ dry weight of shoot and root of cardamom seedlings were recorded from the aforementioned growth media types, respectively (Table 6).
The observed highest fresh and dry weight of shoot and roots of cardamom seedlings on DCH + ForS + FS (1:1:1), $\mathrm{DCH}+$ ForS $(1: 1)$, and FS + ForS (1:1) media mixture could be due to the effects of media compositions on the soil structure and texture. It also improves the moisture retention capacity of the media, availability, and uptake of nutrients, thereby the seed germination, root penetration, and subsequent growth of shoot enhanced [36, 35] and [14]. This result is supported by the research works of [29, 30, 24, 16], and [17]. Whereas, the recorded lowest results of the fresh and dry weight of shoot and roots from sandy soil alone may be due to low nutrient composition and poor moisture retention capacity of the media, which retarded the growth of cardamom seedlings. This result is also supported by [13] and [19].

Table 6. The fresh and dry weight of shoot and roots of cardamom as influenced by nursery growth media at Teppi.

\begin{tabular}{|c|c|c|c|c|}
\hline Treatments & $\begin{array}{l}\text { Fresh Weight of Shoot (g } \\
\text { plant }^{-1} \text { ) }\end{array}$ & $\begin{array}{l}\text { Fresh Weight of Root (g } \\
\left.\text { plant }^{-1}\right)\end{array}$ & $\begin{array}{l}\text { Dry Weight of Shoot (g } \\
\text { plant }^{-1} \text { ) }\end{array}$ & $\begin{array}{l}\text { Dry Weight of Root (g } \\
\text { plant }^{-1} \text { ) }\end{array}$ \\
\hline Fine Sandy Soil (FS) & $10.29 \mathrm{~b}$ & $5.25 \mathrm{~b}$ & $1.4 \mathrm{~b}$ & $0.50 \mathrm{~b}$ \\
\hline Forest Soil (ForS) & $27.83 b$ & $8.50 \mathrm{ab}$ & $3.00 \mathrm{a}$ & $0.78 \mathrm{ab}$ \\
\hline FS + ForS $(1: 1)$ & $30.33 a$ & $13.50 \mathrm{a}$ & $3.25 \mathrm{a}$ & $1.27 \mathrm{a}$ \\
\hline FS + DCH $(1: 1)$ & $28.21 \mathrm{ab}$ & $11.42 \mathrm{ab}$ & $2.85 \mathrm{ab}$ & $0.94 \mathrm{ab}$ \\
\hline ForS + DCH $(1: 1)$ & $41.83 \mathrm{a}$ & $14.29 \mathrm{a}$ & $4.37 \mathrm{a}$ & $1.28 \mathrm{a}$ \\
\hline FS + ForS + DCH $(1: 1: 1)$ & $36.83 \mathrm{a}$ & $12.92 \mathrm{a}$ & $3.54 \mathrm{a}$ & $1.01 \mathrm{a}$ \\
\hline $\mathrm{CV}(\%)$ & 34.70 & 37.70 & 33.36 & 36.10 \\
\hline
\end{tabular}

FS=Fine Sandy Soil; ForS=Forest Soil; DCH=Decomposed Coffee Husk

The observed highest fresh and dry weight of shoot and roots of cardamom seedlings on DCH + ForS + FS (1:1:1), $\mathrm{DCH}+$ ForS $(1: 1)$, and FS + ForS $(1: 1)$ media mixture could be due to the effects of media compositions on the soil structure and texture. It also improves the moisture retention capacity of the media, availability, and uptake of nutrients, thereby the seed germination, root penetration, and subsequent growth of shoot enhanced [19, 36, 35, 34]. This result is supported by the research works of [29, 30, 24, 16] and [17]. Whereas, the recorded lowest results of the fresh and dry weight of shoot and roots from sandy soil alone may be due to low nutrient composition and poor moisture retention capacity of the media, which retarded the growth of cardamom seedlings. This result is also supported by $[13,19]$.

\section{Conclusion}

In general, the study indicated that a mixture of decomposed coffee husk + forest soil (1:1) ratio media maintained good results on several cardamom growth parameters such as plant height, tiller number, leaves number, shoot fresh and dry weight, root fresh and dry weight at nursery condition. The study also confirmed the better suitability of decomposed coffee husk + Forst soil (1:1) ratio media for good establishment of growth traits, for instance, leaf length and leaf area. Hence, sandy soil + forest soil (1:1) ratio mixture was also a suitable medium for root length and root volume of cardamom seedlings. Therefore, from this study, we concluded that better cardamom seedling growth and development can be achieved from coffee husk + forest soil (1:1) growth medium so, framers around the study area and similar agro-ecology of Ethiopia will use this recommendation for better cardamom seedling establishment. Further, research should focus on the performance of seedlings on the field irrespective of yield and yield component traits.

\section{Acknowledgements}

The authors' thanks to the Ethiopian Institute of Agricultural Research (EIAR) for the financial support and the Tepi Agricultural Research Center for providing all the necessary materials and logistics for this study. We also give our due appreciation for our process research field assistance namely, Mr. Wondifraw Derib, Mr. Wondimu Gebresillasie, and Mr. Aschalew Bekele, for their unreserved support on fieldworks from nursery media preparation up to data collection.

\section{References}

[1] Abayneh, E. and Ashenaf, A. 2005. Soils of Tepi and Haru Agricultural Research Sub centers, soil survey and land evaluation section. National Soil Research Center. Ethiopian Institute of Agricultural Research, Addis Ababa, Ethiopia.

[2] Ankegowda S. 2008. Optimum leaf stage for transplanting small cardamom seedlings from primary nursery to polybag nursery. Short communication. Indian J. Horti. Vol. 65 (2): 252-254. 
[3] Anteneh, N. and Taye, K. 2015. Review of Arabica Coffee Nursery Management Research in Ethiopia. J. Bio., Agri. \& Healt. Vol. 5 (11): 20-23.

[4] Baiyeri, K. and Mbah, B. 2006. Effects of soilless and soil based nursery media on seedling emergence, growth and response to water stress of African breadfruit (Treculia africana Decne). Afr. J. Biotechnol, 5: 1405-1410.

[5] Baiyeri, K. 2005. Response of Musa Species to MacroPropagation: II: The effects of genotype, initiation and weaning media on sucker growth and quality in the nursery. Afr. J. Biotechnol. 4 (3): 229-234.

[6] Chinnasamy V, Subramaniyan V, Chandiran S, Kayarohanam S, Kanniyan DC, Velaga VSSR, Muhammad S. Antiarthritic Activity of Achyranthes Aspera on Formaldehyde - Induced Arthritis in Rats. Open Access Maced J Med Sci. 2019; 7 (17): 2709-2714.

[7] Dereje, G. and Eshetu, A. 2011. Agro-ecologies of Ethiopia and major crops grown. A research report in collaboration with Ethiopian Institute of Agricultural Research (EIAR). Addis Ababa, Ethiopia.

[8] Edossa Etissa. 1998. Spices research achievements and experiences. Research Report No. 33. Institute of Agricultural Research, Addis Ababa Ethiopia.

[9] Girma, H., Digafie, T. and Habtewold, K. 2011. Establishment and Management of Spices Nursery, Tepi National Spices Research Center, Ethiopian Institute of Agricultural Research (EIAR), Addis Ababa Ethiopia, (Amharic Version).

[10] Girma H., Digafie T., Edossa E., Belay Y. and Weyessa G. 2008a. Spices research achievements, revised edition, Ethiopian Institute of Agricultural Research, Addis Ababa Ethiopia.

[11] Girma H. 2008b. Spices (black pepper, ginger, turmeric and cardamom) production and postharvest handling; In: EIAR (eds), Ethiopian Institute of Agricultural Research (EIAR). Utilization of Crop Technologies: ISBN: 978-99944-53-09-PP. 118-133, Addis Ababa, Ethiopia.

[12] Gomez KA, Gomez AA (1984). Statistical procedures for Agricultural Research. 2nd ed. John wily \& Sons, New York.

[13] Goh, K. and Haynes, R. 1977. Evaluation of potting media for commercial nursery production of container-grown plants. New Zealand J. Agri. Res., Vol. 20 (3): 363-370.

[14] Hafeez, R., Muhammad, R., Ghulam N. and Abdul, S. 2007. Effect of soil media on peach seed germination and seedling growth in climatic conditions of orakzai agency (fata). Sarhad Journal Agriculture, 23 (3).

[15] Hassen S. 2020. Effect of Watering Frequency and Growth Media on Seed Germination and Subsequent Seedling of Cardamom (Elleteria Cardamom) at Tepi South-Western Part of Ethiopia, Journal of Biology, Agriculture and Healthcare. 10 (7): 2224-3208.

[16] Jafer D. 2019. "Effect of seed treatment and nursery potting media on emergence and seedling growth of Korarima (Aframomum cororima (Braun) P.C.M.Jansen)". Inter. J. Res. Stu. Sci. Engi. \& Tech., Vol. 6 (12): 13-19.

[17] Jafer D. 2020. "Seedling growth rate of Korarima (Aframomum cororima (Braun) P.C.M. Jansen) response to soil resource and seed treatment". Inter. J. Res. Agri. \& Fore,
Vol. 7 (8): 01-07.

[18] Kumar PK, Radhakrishnan VV, Hrideek TK, Sunil S, Kuruvilla KM, Sudharshan MR (2015) Shade trees and forage behaviour of honey bees in cardamom plantations. In: Mohanan et al (eds) Prospects in forestry and agriculture. Kerala Forest Research Institute KFRI, Peechi, India, pp 112117.

[19] Lupi A., Temeteme S., Mitiku T., Mekonnen, B., et al., 2016. Influence of rooting media on nursery performance of Korarima (Aframomum cororima (Braun) P.C.M. Jansen) in Southwest of Ethiopia. Aca. Res. J. Agri. Sci. \& Res., Vol. 4 (2): 61-65.

[20] Murphy, H. 1968. A research report on fertility status and other data on some soils of Ethiopia. Experimental Station Bulletin, No. 44. Haile Silassie College of Agriculture, Oklahoma State University.

[21] Neelam, A. and Ishtiaq, M. 2001. Response of Eucalyptus camaldulensis seedlings to different soil media. Sarhad $J$. Agric. Vol. 17 (1): 75-79.

[22] Olsen, S., Cole, C., Watanabe, F. and Dean, L. 1954. Estimation of available phosphorus in soils by extraction with sodium bicarbonate. USDA Circular, Washington, USA 939: $1-19$.

[23] Purseglove, J.W.; Brown, E.G.; Green, C.L. and S.R.J. Robins. 1981. Spices: Volumes 1 and 2. Longman Group Limited, London.

[24] Sahni, S., Sarma, B., Singh, D., Singh, H. and Singh, K. 2008. Vermi-compost enhances performance of plant growth promoting rhizo-bacteria in Cicer arietinum rhizosphere against Sclerotium rolfsii. Crop Protection, Vol. 27:369-376.

[25] SAS (Statistical Analysis System) Institute Inc, 2008. SAS/STAT 9.2 User's Guide. Cary, NC: ${ }^{\circledR}$ SAS Institute Inc. 25 .

[26] Spices Board India .2009. Cultivation practices for cardamom, Smt. K. Lekshmikutty, Niseema Printers \& Publishers, Kochi18, Vol. 22 (3), India.

[27] TARC. 2013. Summary of survey on spices production practices in Tepi and Yeki areas. Socio- economics department of Tepi Agricultural Research Center (unpublished).

[28] Taye, K., Tesfaye, S. and Alemseged, Y. 2008. Influence of Media mixture, watering frequency on seed germination and seedling growth of Arabia coffee in Ethiopia. In: Girma Adugna, Bayetta Belachew, Tesfaye Shimber, Endale Taye and Taye Kufa (eds.). In: Proceedings of a national workshop, four decade and development Ethiopia 14-17 August 2007, Addis Ababa (Ghion Hotel), Ethiopia. Pp. 307-316.

[29] Taye, K. 1998. Response of Arabica coffee (Coffea arabica L.) to various soil fertility management response of Arabica coffee (Coffea arabica L.) to various soil fertility management. An M.Sc. Thesis presented to the school of graduate studies Alemaya University, Alemaya, Ethiopia.

[30] Taye, K., Mesfin, A. and Paulos, D. 1999. Effect of nitrogen, phosphorus and organic fertilizer on growth and development of coffee seedlings. Pp.213-223. In: Proceedings of African Crop Science Conference. African Crop Science Society, Vol. 4, Kampala, Uganda. 
[31] Tekalign, T. 1991. Soil, plant, water, fertilizer, animal manure and compost analysis. Working Document No. 13. International Livestock Research Center for Africa, Addis Ababa, Ethiopia.

[32] Tiwari RS, and Agarwal A.2004. Production Technology of Spices. International Book Distributing Co. India.

[33] Venkateshan S, Subramaniyan V, Chinnasamy V, Chandiran S. Anti-oxidant and anti-hyperlipidemic activity of Hemidesmus indicus in rats fed with high-fat diet. Avicenna J Phytomed. 2016; 6 (5): 516-525.

[34] Vetriselvan Subramaniyan, Saminathan Kayarohanam, Ashok Kumar J, \& Vinoth Kumarasamy. (2019). Impact of herbal drugs and its clinical application. International Journal of Research in Pharmaceutical Sciences, 10 (2), 1340-1345.
[35] Vineeta, M. and Agnihotri, A. 2005. Source of organic manure. Agrobios. Newsletter, Jodphur, India. Vol. 4 (7): 1112.

[36] Wootton, R., Gouin, F. and Stark, F. 1981. Composted, Digested sludge as a medium for flowering annuals. J. Amer. Soc. Hort. Sci. Vol. 106 (1): 46-49.

[37] Wriss, E.A, 2002. Spice crops, CABI Publishing, Wallingford, UK, 2002. 432 pp ISBN 0-85199-6051; (p. 299-316).

[38] Yakob, E., Taye, K. and Alemseged, Y. 1998. Varietal and age impact on Arabica coffee leaf growth parameters at three locations. Proceedings of the $3^{\text {rd }}$ Conference of Agronomy and Crop Physiology Society of Ethiopia, May 29-30, Addis Ababa, Ethiopia, Pp 38-51. 